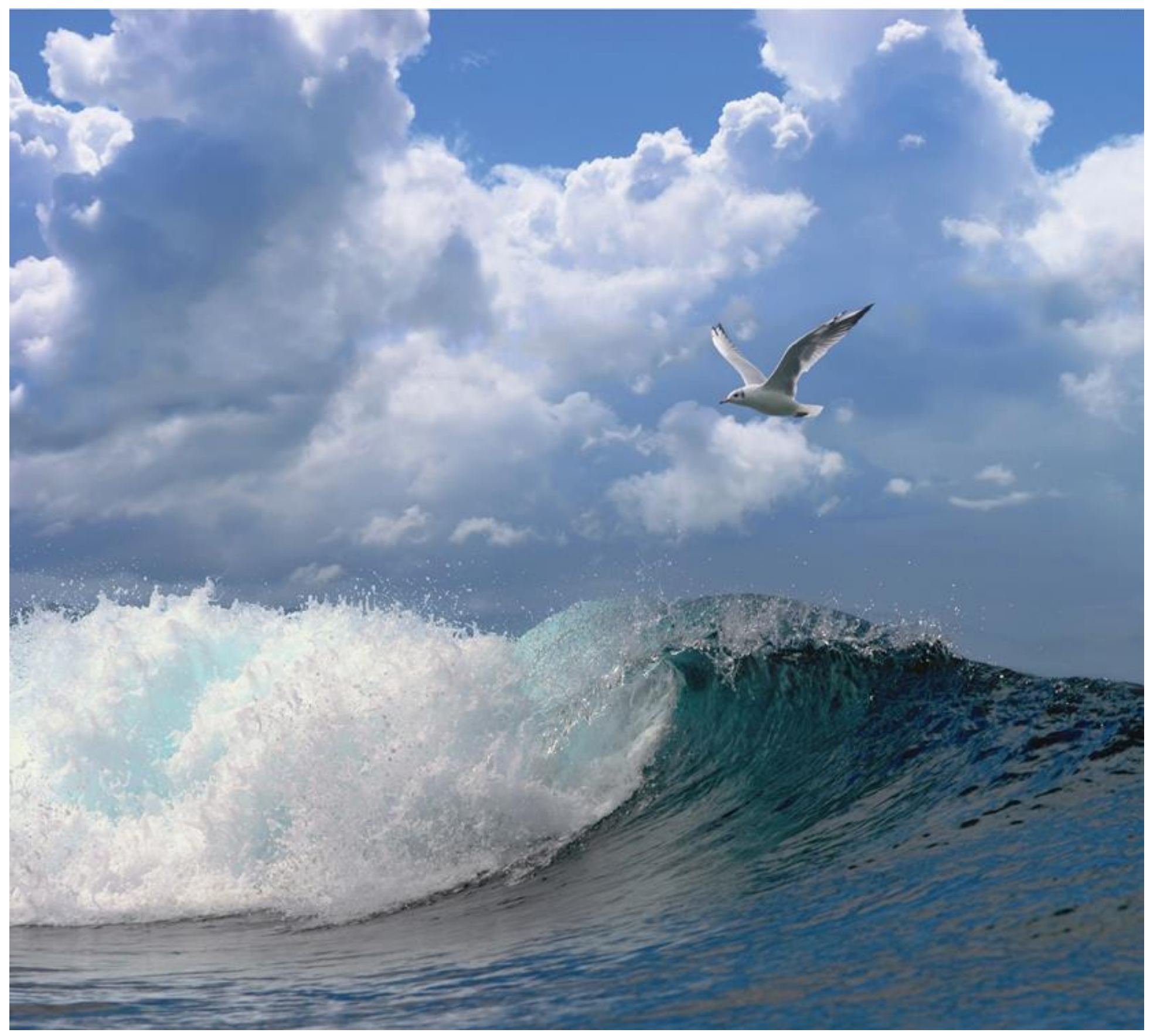

\title{
Marine mammal surveys in Dutch North Sea waters in 2019
}




\section{Marine mammal surveys in Dutch North Sea waters in 2019}

Authors: $\quad$ Steve CV Geelhoed, Nicole Janinhoff, Sander Lagerveld \& Hans JP Verdaat

This research project was carried out by Wageningen Marine Research at the request of and with funding from the Ministry of Agriculture, Nature and Food Quality for the purposes of Policy Support Research Theme 'Ecologische basiskwaliteit water' (project no. BO-43-021.02-022). 
Keywords: abundance, aerial survey, distance sampling, distribution, harbour porpoise, Dutch Continental Shelf, North Sea, Phocoena phocoena, population size

Client: $\quad$ Anne-Marie Svoboda

Department of Nature and Biodiversity

Ministry of Agriculture, Nature and Food Quality

Bezuidenhoutseweg 73

2594 AC Den Haag

This report can be downloaded for free from https://doi.org/10.18174/515228

Wageningen Marine Research provides no printed copies of reports.

Wageningen Marine Research is ISO 9001:2015 certified.

\section{(C) Wageningen Marine Research}

Wageningen Marine Research, an institute Wageningen Marine Research accepts no liability for consequential damage, nor within the legal entity Stichting for damage resulting from applications of the results of work or other data Wageningen Research (a foundation under obtained from Wageningen Marine Research. Client indemnifies Wageningen Dutch private law) represented by $\mathrm{Dr}$. Marine Research from claims of third parties in connection with this application. M.C.Th. Scholten, Managing Director All rights reserved. No part of this publication may be reproduced and / or

KvK nr. 09098104, published, photocopied or used in any other way without the written permission

WMR BTW nr. NL 8113.83.696.B16. of the publisher or author.

Code BIC/SWIFT address: RABONL2U

IBAN code: NL 73 RABO 0373599285 


\section{Contents}

$\begin{array}{lr}\text { Summary } & 4\end{array}$

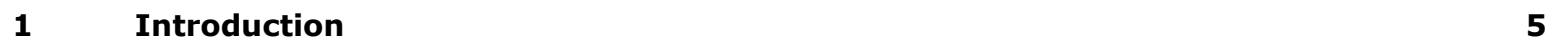

2 Assignment $\quad 6$

$3 \quad$ Materials and Methods $\quad 7$

$\begin{array}{lll}3.1 & \text { Study area, survey design and data acquisition } & 7\end{array}$

3.2 Data quality check and data storage $\quad 8$

3.3 Data analysis $\quad 8$

$\begin{array}{llr}\text { Results } & 10\end{array}$

$\begin{array}{lll}4.1 & \text { Weather conditions and survey effort } & 10\end{array}$

4.2 Harbour Porpoise sightings - pod size and behaviour 11

4.3 Harbour Porpoise - distribution 11

4.4 Harbour Porpoise - densities and abundance estimates $\quad 12$

$\begin{array}{lll}4.5 & \text { Other marine mammals - sightings } & 13\end{array}$

$\begin{array}{llr}5 & \text { Discussion } & 15\end{array}$

6 Conclusions $\quad 16$

$\begin{array}{llr}7 & \text { Quality Assurance } & 17\end{array}$

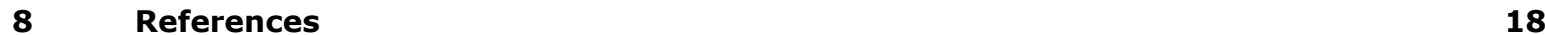

$\begin{array}{lr}\text { Justification } & \mathbf{2 1}\end{array}$ 


\section{Summary}

Aerial surveys to estimate the abundance of Harbour Porpoise Phocoena phocoena were conducted on the Dutch Continental Shelf in summer 2019. These surveys followed predetermined track lines in four areas: A - Dogger Bank, B - Offshore, C - Frisian Front \& D - Delta. Between 16 July and 4 August the entire Dutch Continental Shelf (DCS) was surveyed.

Marine mammals were assessed using line transect distance sampling methods. Density and abundance estimates were calculated. In total, 150 sightings of 189 individual Harbour Porpoises were collected. Porpoise densities varied between 0.54-1.76 animals $/ \mathrm{km}^{2}$ in the areas A-D. The overall density was 0.66 animals $/ \mathrm{km}^{2}$. The lowest density $\left(0.46\right.$ animals $\left./ \mathrm{km}^{2}\right)$ was recorded in area A - Dogger Bank. The densities in the other areas were in the same order of magnitude, ranging between 0.68-071 animals $/ \mathrm{km}^{2}$.

In summer 2019 the total number of Harbour Porpoises on the Dutch Continental Shelf (areas A-D) was estimated at 38,911 individuals ( $C I=20,791-76,822)$. This estimates falls in the range of abundance estimates since 2010, with a minimum of 25,998 (CI = 13,988 - 53,623 in 2010) and a maximum of 76,773 ( $C I=43,414-154,265$ in 2014) individuals. The confidence intervals of the abundance estimates overlap, indicating no statistically significant differences between the years. The time series, however, is relatively short to measure trends.

These abundance estimates show that up to a fifth of the North Sea population, estimated at 345,000361,000 individuals, has been present on the Dutch Continental Shelf during the summer surveys in 2010-2019.

The results of these aerial surveys will feed into the OSPAR MSFD indicator on abundance and distribution of marine mammals.

In total 26 sightings of other marine mammal species than Harbour Porpoises were recorded. These comprised 22 sightings of seals (Grey Seal Halichoerus grypus and Harbour Seal Phoca vitulina). The majority of the seals was observed in coastal waters off the Wadden Isles. Three single Minke Whales Balaenoptera acutorostrata were seen (feeding) in area A - Dogger Bank and B - Offshore, with another one sighted off effort in the same area. One sighting of a pod of two White-beaked Dolphins Lagenorhynchus albirostris was made in area B - Offshore.

This research is part of the BO-project 'monitoring bruinvis'. 


\section{Introduction}

In the Dutch Harbour Porpoise conservation plan (Camphuysen \& Siemensma, 2011) abundance estimates of the Dutch population of Harbour Porpoise Phocoena phocoena have been identified as one of the research needs with the highest priority. These assessments are needed to monitor the density and distribution of this protected species. They can be used to describe trends in national waters, efficacy of management actions as well as to evaluate potential impacts of anthropogenic activities.

Abundance estimates for the entire Dutch Continental Shelf were lacking until 2010 (Scheidat et al., 2012). In July 2010-March 2011, under the umbrella of the Shortlist Masterplan Wind programme, dedicated aerial surveys of the entire Dutch Continental Shelf were conducted for the first time, in three different seasons (Geelhoed et al., 2011 \& 2013a). These surveys resulted in abundance estimates and distribution maps of Harbour Porpoises, thus providing a baseline for subsequent surveys in order to study annual and seasonal variations in the numbers and distribution of porpoises in Dutch waters.

As a follow-up, surveys of the Dutch Continental Shelf were conducted in spring 2012 and 2013 (Geelhoed et al., 2013b, 2014a), summer 2014, 2015, 2017 and 2018 (Geelhoed et al., 2014b; 2015;, 2018ab; Geelhoed \& Scheidat, 2018). In this report we present the results of the aerial surveys conducted in July-August 2019. It was the sixth time ever a complete dedicated survey of Dutch waters took place in summer.

These surveys are conducted under the umbrella of the BO-project monitoring bruinvis, funded by the Ministry of Agriculture, Nature and Food Quality of The Netherlands. Apart from aerial surveys this BOproject contains diet studies, and studies on contaminant loads in stranded harbour porpoises. The results of these studies are published separately. 


\section{Assignment}

This report presents the aerial survey results using line transect distance sampling as described in the original assignment of KRM monitoring bruinvis, a continuation of the Beleidsondersteunend Onderzoek program of the Ministry of Economic Affairs. This assignment consisted of aerial surveys of marine mammals on the entire Dutch Continental Shelf in 2019. 


\section{Materials and Methods}

\subsection{Study area, survey design and data acquisition}

The study area included the entire Dutch section of the continental shelf $\left(59,417 \mathrm{~km}^{2}\right)$. The study area was divided into four sub-areas: A - Dogger Bank $\left(9,615 \mathrm{~km}^{2}\right)$, B - Offshore $\left(16,892 \mathrm{~km}^{2}\right), \mathrm{C}$ - Frisian Front $\left(12,023 \mathrm{~km}^{2}\right)$ and $D$ - Delta $\left(20,797 \mathrm{~km}^{2}\right)$ (Figure 1). The design of the track line set-up was chosen to be parallel in areas $C$ and $D$ and zigzag in area $A$ and $B$ to ensure a representative coverage of the sub-areas and minimize off effort time between track lines. In addition, the direction of track lines followed depth gradients in order to get a better sample by minimising variance in encounter rates between transect lines (Buckland et al., 2001). The survey design has been the same since the first aerial surveys were conducted in 2008 (Scheidat et al., 2012).

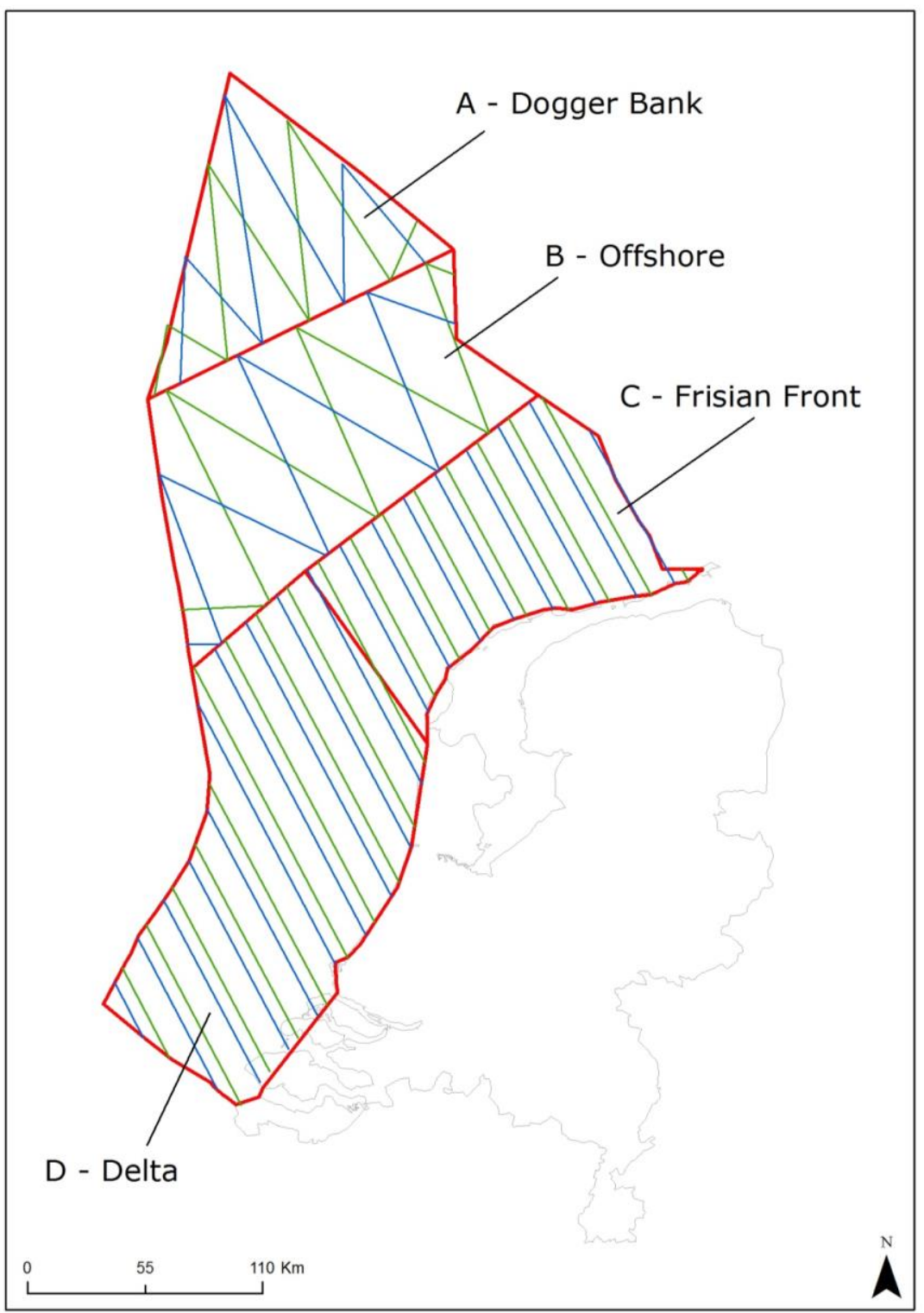

Figure 1. Map of the Dutch Continental Shelf with the planned track lines in study areas A - Dogger Bank, B Offshore, C - Frisian Front and D - Delta. Colours indicate sets of track lines.

Surveys were conducted with a Partenavia 68, a high-winged twin-engine airplane equipped with bubble

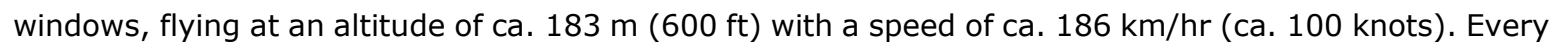
four seconds the aircraft's position and time (to the nearest second) were recorded automatically onto a laptop computer connected to a GPS. Surveys were conducted by a team of three people. Sighting 
information and details on environmental conditions were entered by one person (the navigator) at the beginning of each transect and whenever conditions changed. Observations were made by two dedicated observers located at the bubble windows on the left and right sides of the aircraft. For each observation the observers acquired sighting data including species (all cetaceans and seals), declination angle measured with an inclinometer from the aircraft abeam to the group, group size, presence of calves, behaviour (Table 1), swimming direction, cue, and reaction to the survey plane. The perpendicular distances from the transect to the sighting were later calculated from aircraft altitude and declination angle. Environmental data included sea state (Beaufort scale), turbidity (4 classes, assessed by visibility of objects below the sea surface), cloud cover (in octaves), glare and subjective sighting conditions (Table 2). These sighting conditions represent each observer's subjective view of the likelihood that the observer would see a harbour porpoise within the search area should one be present, and could differ between left and right.

Table 1. Behavioural codes and description for marine mammals.

\begin{tabular}{ll}
\hline Code & Behaviour \\
\hline Sw & directional swimming \\
Fasw & fast directional swimming or porpoising \\
Mill & milling, non-directional swimming \\
Log & resting/logging: not moving at the surface \\
Feed & Feeding \\
Headup & spyhop of seals vertically in the water column \\
Other & other behaviour, noted down in comments \\
\hline
\end{tabular}

Table 2. Description of subjective sighting conditions.

\begin{tabular}{ll}
\hline Sighting condition & Description \\
\hline Good (G) & $\begin{array}{l}\text { Observer's assessment that the likelihood of seeing a porpoise, should one } \\
\text { occur within the search area, is good. Normally, good subjective conditions } \\
\text { will require a sea state of two or less and a turbidity of less than two. } \\
\text { Observer's assessment that the likelihood of seeing a porpoise, should one } \\
\text { occur within the searching area, is moderate. A subdivision between wicked } \\
\text { (W) leaning towards good, and sucks (S) leaning towards poor is made. } \\
\text { Observer's assessment that it is unlikely to see a porpoise, should one occur } \\
\text { Poor (P) }\end{array}$ \\
$\begin{array}{l}\text { Nothin the search strip. } \\
\text { observe }(\mathrm{X})\end{array}$ & Observer off effort due to adverse circumstances \\
\hline
\end{tabular}

Surveys were conducted in weather conditions safe for flying operations (no fog or rain, visibility $>3 \mathrm{~km}$ ) and suitable for porpoise surveys (Beaufort sea state equal or less than 3). Surveys were conducted by Martin Baptist, Steve Geelhoed, Nicole Janinhoff and Hans Verdaat as observer and navigator. Peter Reijnhout from Zeelandair was the pilot.

\subsection{Data quality check and data storage}

All collected data was checked, e.g. for consistency of codes, corrected and subsequently stored in the Dutch database.

\subsection{Data analysis}

The survey data were collected using distance sampling techniques (Buckland et al., 2001; 2004). The collected sightings are used to calculate densities and abundance estimates, and to produce distribution maps. Only data from transect lines flown in good or moderate conditions were used in the analyses. Densities and abundance estimates were calculated according to distance sampling methods, that yield absolute densities, i.e., the number of animals $/ \mathrm{km}^{2}$ with the associated $95 \%$ confidence interval (CI) and coefficient of variation (CV; Buckland et al., 2001). To do this the so called effective strip half-width 
(ESW) is calculated. The ESW is calculated for each side of the track line separately. To obtain the first component to calculate the ESW the perpendicular distance of a sighting to the track line is measured. To calculate the distance of the sighting to the track line from air, the plane's altitude $(600$ feet $=183 \mathrm{~m}$ ) and the vertical or 'declination' angle to the animal are used. The latter is measured when it comes (or is estimated to come) abeam. By modelling a detection curve to all these distances the effective strip half-width is obtained; this is defined as the distance at which the expected number of detected objects would be the same as for the actual survey (Buckland et al., 2001).

One of the assumptions of line-transect distance sampling is that all animals on the track line are detected, which would mean that the chance to see all animals at a distance of $0 \mathrm{~m}$ from the track line is $1(100 \%)$. For most animals, but in particular for cetaceans, this assumption is not true and a correction factor, called $\mathrm{g}(0)$, needs to be obtained to correct for the proportion of animals missed on the track line. In practice there are two reasons why animals are not recorded: 1 . the animals are not "available" to be seen, (e.g. because they are sub-merged) or 2. they are missed by the observers ("observer bias"). To obtain a reliable estimate of absolute abundance (the number of animals in a given area e.g., the DCS) it is therefore needed to estimate the proportion of animals actually seen on the track line: the true value of $\mathrm{g}(0)$, and use the reciprocal of this value to correct the ESW. In the analysis $\mathrm{g}(0)$ values of 0.37 for good conditions and 0.14 for moderate conditions are used (taken from Scheidat et al., 2008).

Animal abundance in each stratum v (sub-areas A, B, C and D) was estimated using a HorvitzThompson-like estimator (Buckland et al., 2001; 2004) as follows:

$$
\hat{N}_{v}=\frac{A_{v}}{L_{v}}\left(\frac{n_{\mathrm{gs} v}}{\hat{\mu}_{\mathrm{g}}}+\frac{n_{\mathrm{ms} v}}{\hat{\mu}_{\mathrm{m}}}\right) \bar{s}_{v}
$$

where $A v$ is the area of the stratum, $L_{v}$ is the length of transect line covered on-effort in good or moderate conditions, $\mathrm{n}_{\mathrm{gsv}}$ is the number of sightings that occurred in good conditions in the stratum, $\mathrm{n}_{\mathrm{msv}}$ is the number of sightings that occurred in moderate conditions in the stratum, $\mu_{\mathrm{g}}$ is the estimated total effective strip width in good conditions, $\mu_{\mathrm{m}}$ is the estimated total effective strip width in moderate conditions and $\bar{S}_{v}$ is the mean observed school size in the stratum.

Group abundance by stratum was estimated by $\quad \hat{N}_{v(\text { group })}=\hat{N}_{v} / \bar{S}_{v}$

Total animal and group abundances of the entire Dutch Continental Shelf were estimated by:

$$
\hat{N}=\sum_{v} \hat{N}_{v} \quad \text { and } \quad \hat{N}_{\text {(group) }}=\sum_{v} \hat{N}_{v \text { (group) }}
$$

respectively. Densities were estimated by dividing the abundance estimates by the area of the associated stratum. Average group size across strata was estimated by $E[s]=N / N_{\text {(group) }}$. Coefficients of variation (CV) and $95 \%$ confidence intervals (CI) were estimated by a non-parametric bootstrap (999 replicates) within strata, using transect segments as the sampling units. The variance due to estimation of ESW was incorporated using a parametric bootstrap procedure which assumes the ESW estimates to be normally distributed random variables. More details on this method can be found in Scheidat et al. (2008; 2012).

Distribution maps were created by calculating densities per $1 / 9$ ICES grid cell. This $1 / 9$ ICES grid has latitudinal rows at intervals of 10', and longitudinal columns at intervals of 20'. ICES $1 / 9$ rectangles intersecting with the DCS measure approximately 20x20km, resulting in areas ranging from 388 to 409 $\mathrm{km}^{2}$, depending on latitude.

Densities per 1/9 ICES grid cell were calculated by dividing the total number of animals observed during good and moderate conditions by the total surveyed area. The surveyed area is the distance travelled multiplied by the total effective strip width (ESW). The effective strip half-width (ESW corrected for $g(0)$ values) was defined as $76.5 \mathrm{~m}$ for good sighting conditions and $27 \mathrm{~m}$ for moderate sighting conditions on each side of the track line (Gilles et al., 2009; Scheidat et al., 2008). Densities in grid cells extending outside the borders of the surveyed area (e.g., the Wadden Sea) could be less reliable due to lower effort and habitat discontinuities within the grid cell. Grid cells with an effort less than $1 \mathrm{~km}^{2}$ were omitted from the density calculations. 


\section{Results}

\subsection{Weather conditions and survey effort}

The entire Dutch Continental Shelf was surveyed on three extensive days in the period 16 July-4 August (Figure 2, Table 3). Adverse and rapidly changing weather conditions after 17 July made it impossible to survey areas A - Dogger Bank and B - offshore shortly after the first flights. All in all, a total distance of $2142.2 \mathrm{~km}$ was surveyed on effort. Of this distance $76.5 \%$ was surveyed with good or moderate conditions on at least one side of the plane (Table 4).
16 July
17 July
4 August
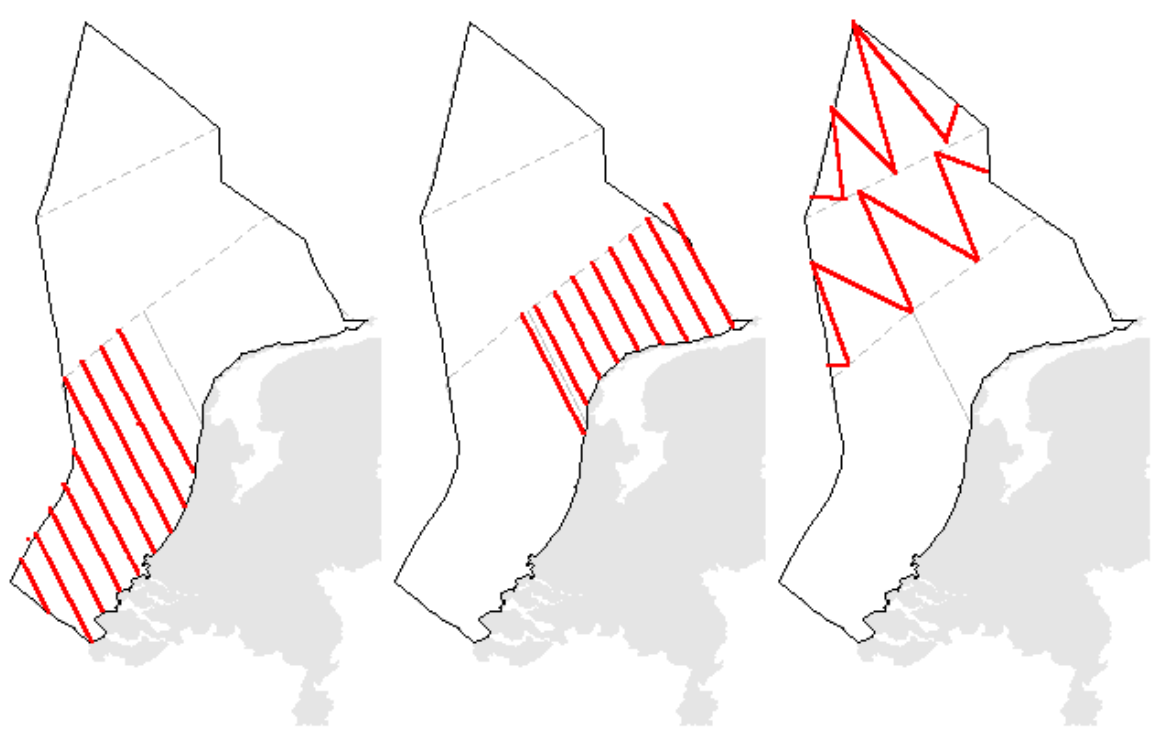

Figure 2. Survey effort per day July-August 2019.

Table 3. Survey dates and surveyed areas in July-August 2019.

\begin{tabular}{ll}
\hline Survey date & Surveyed area \\
\hline 16 July & Area D - Delta \\
17 July & Area C - Frisian Front \& Area D - Delta \\
4 August & Area A - Dogger Bank \& Area B - Offshore \\
\hline
\end{tabular}

Table 4. Total survey days, effort (surveyed distance), sighting conditions ( $g$ - good, $m$ - moderate, $p-$ poor, $x$ - not possible to observe) and Harbour Porpoise sightings on both sides during the aerial surveys in July-August 2019. Navigator sightings are excluded.

\begin{tabular}{ccccccccc}
\hline \multirow{2}{*}{ Effort $(\mathbf{k m})$} & \multicolumn{3}{c}{ Sighting conditions (\%) } & & \multicolumn{3}{c}{ Harbour Porpoise sightings (n) } \\
\cline { 2 - 4 } & $\mathbf{G}$ & $\mathbf{~ m}$ & $\mathbf{p} / \mathbf{x}$ & & Sightings & Individuals & Calves \\
\hline 2142.2 & 11.6 & 64.9 & 23.5 & & 150 & 189 & 12 \\
\hline
\end{tabular}




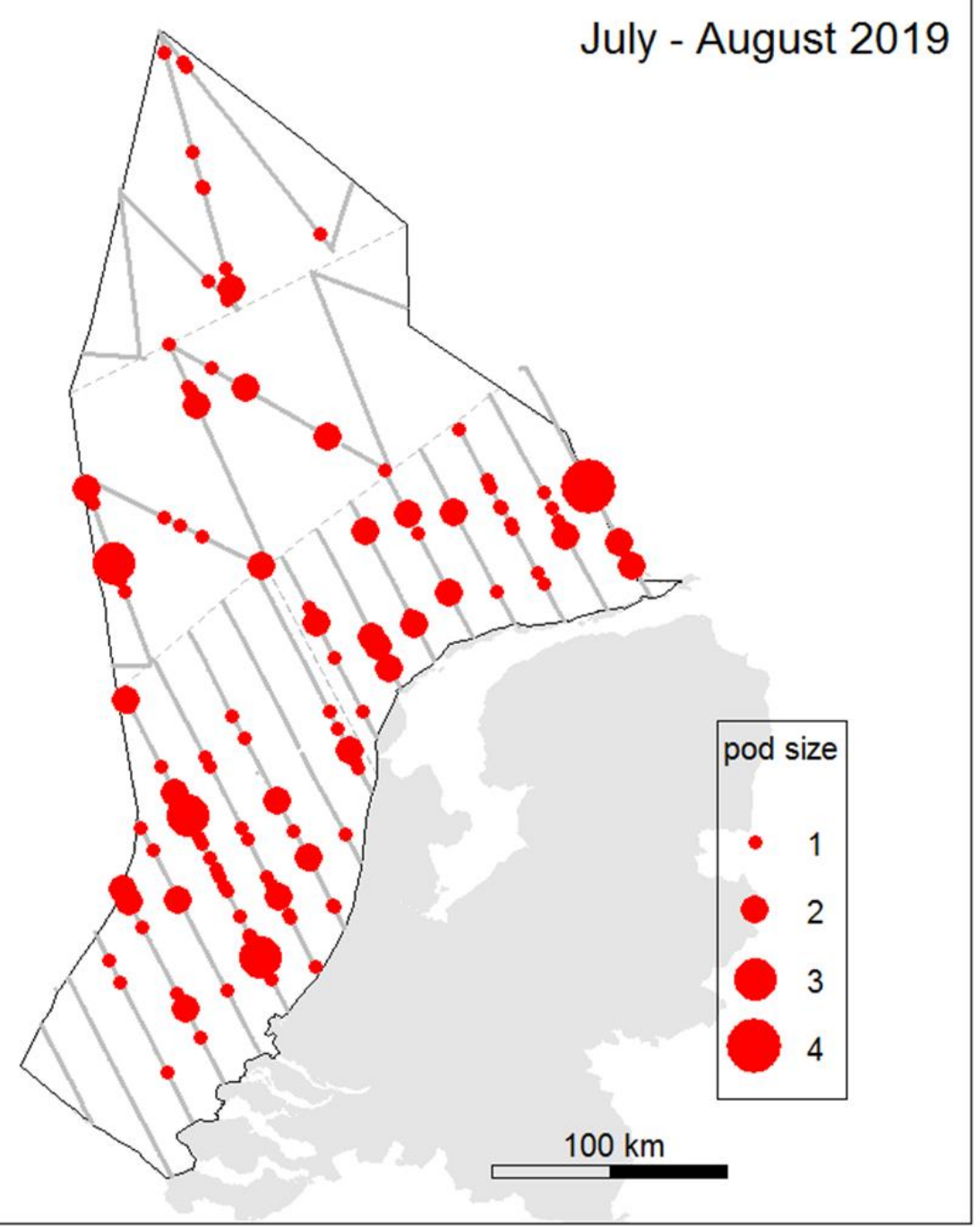

Figure 3. Harbour Porpoise sightings during the DCS survey in July-August $2019(n=150)$.

\subsection{Harbour Porpoise sightings - pod size and behaviour}

In total, 150 sightings with 189 individual Harbour Porpoises, including 12 calves (6\%), were collected (Table 4). These sightings are shown in Figure 3. Most sightings concerned single individuals, with an average pod size of 1.3 individuals.

The majority of the sightings concerned directionally swimming animals $(69 \%, \mathrm{n}=103) ; 16 \%$ was milling or resting at the surface $(n=25)$. One animal was qualified as feeding, associated with a fish ball, and attracted seabirds.

\subsection{Harbour Porpoise - distribution}

The distribution of porpoises (animals $/ \mathrm{km}^{2}$ ) per $1 / 9$ ICES grid cell is shown in Figure 4 . Harbour Porpoises were widely distributed and showed a homogenous distribution in a band from area D - Delta north to the southern part of area B - offshore. The distribution was more patchy in the areas north of this band, but Harbour Porpoises were virtually absent in large areas in northern part of area $B$ - offshore and the adjacent southern part of area A - Dogger Bank. 


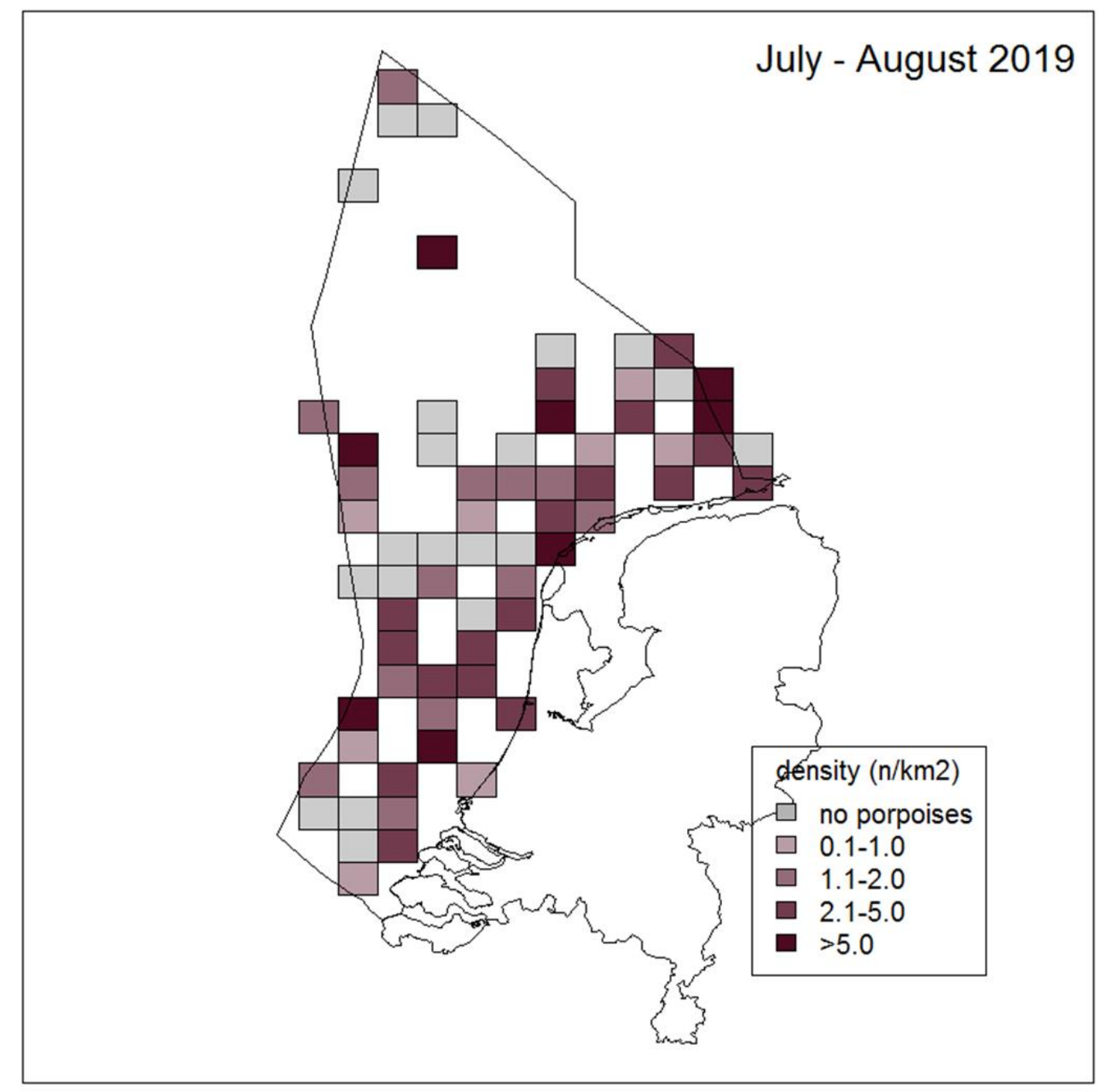

Figure 4. Density distribution of Harbour Porpoises (animals $/ \mathrm{km}^{2}$ ) per 1/9 ICES grid cell, July-August 2019. Only sightings under good and moderate conditions were used. Grid cells with low effort $\left(<1 \mathrm{~km}^{2}\right)$ are omitted.

\subsection{Harbour Porpoise - densities and abundance estimates}

Densities of Harbour Porpoises were estimated for each survey stratum (areas A-D) as well as for the whole DCS. Table 5 gives an overview of density (animals $/ \mathrm{km}^{2}$ ) as well as abundance estimate (number of animals) per survey area. The overall density was 0.66 animals $/ \mathrm{km}^{2}$. The lowest density $(0.46$ animals $/ \mathrm{km}^{2}$ ) was recorded in area A - Dogger Bank. The densities in the other areas were in the same order of magnitude, ranging between $0.68-071$ animals $/ \mathrm{km}^{2}$ (Table 5).

Table 5. Abundance estimates of Harbour Porpoises for July-August 2019 per area.

\begin{tabular}{lccccc}
\hline & $\begin{array}{c}\text { Density } \\
\text { (animals } / \mathbf{k m}^{2} \text { ) }\end{array}$ & $\mathbf{9 5 \%} \mathbf{~ C I}$ & $\begin{array}{c}\text { Abundance } \\
\text { (n animals) }\end{array}$ & $\mathbf{9 5 \% ~ C I ~}$ & CV \\
\hline Area A - Dogger Bank & 0.46 & $0.11-1.05$ & 4380 & $1017-10,056$ & 0.51 \\
Area B - Offshore & 0.68 & $0.29-1.39$ & 11,557 & $4825-23,437$ & 0.38 \\
Area C - Frisian Front & 0.69 & $0.40-1.34$ & 8262 & $4780-16,093$ & 0.32 \\
Area D - Delta & 0.71 & $0.24-1.64$ & 14,713 & $4987-34,130$ & 0.48 \\
\hline Total DCS & 0.66 & $0.35-1.39$ & 38,911 & $20,791-76,822$ & 0.35 \\
\hline
\end{tabular}

These densities correspond to a total number of Harbour Porpoises on the Dutch Continental Shelf (areas A-D) of 38,911 animals ( $C I=20,791-76,822$, Table 5 ) in July -August 2019. The numbers of animals 
were more or less proportionately distributed over the areas, with areas B, C and D holding $88.7 \%$ of all animals, whilst they comprise $83.4 \%$ of the total area of the DCS.

\subsection{Other marine mammals - sightings}

During the surveys 27 sightings of other marine mammal species were made on effort (Table 6). Two other cetacean species than Harbour Porpoise were observed: Minke Whale Balaenoptera acutorostrata., and White-beaked Dolphin Lagenorhynchus albirostris. Three Minke Whales were seen in the northern part of the DCS, in area A Dogger Bank and in the northwest corner of area B - Offshore on the 4th of August (Figure 5). Several fish balls and feeding seabirds were also seen in these areas. One of the Minke Whales was feeding, accompanied by tens of Northern Gannets Morus bassanus and Black-legged Kittiwakes Rissa tridactyla. Off effort one more sighting of a single animal was made in this area. One small pod of two White-beaked Dolphins was seen in area B - Offshore (Figure 6).

Seals (Grey Seal Halichoerus grypus and Harbour Seal Phoca vitulina) were seen in all areas, but the majority was seen in the vicinity of the coast, with a concentration north of the Wadden Isles near their haul out sites (Figure 7). Most seals were not identified to species level, but Grey Seals $(n=4)$ were seen in Areas B - Offshore and in the northwest of area D - Delta. The coastal sightings were not identified to species level, but the majority was tentatively identified as Harbour Seal. Numbers of seals, Minke Whale and White-beaked Dolphin were too low to calculate densities and abundance estimates.

Table 6. Total survey days, effort (surveyed distance), and on effort sightings of marine mammals other than Harbour Porpoise during the aerial surveys in July-August 2019.

\begin{tabular}{|c|c|c|c|c|c|c|}
\hline \multirow{2}{*}{$\begin{array}{l}\text { Effort } \\
(\mathbf{k m})\end{array}$} & \multicolumn{2}{|c|}{ Minke Whale } & \multicolumn{2}{|c|}{ White-beaked Dolphin } & \multicolumn{2}{|l|}{ Seals } \\
\hline & Sightings & $\mathbf{N}$ & Sightings & $\mathbf{N}$ & Sightings & $\mathbf{N}$ \\
\hline 2142.2 & 3 & 3 & 1 & 2 & 22 & 23 \\
\hline
\end{tabular}

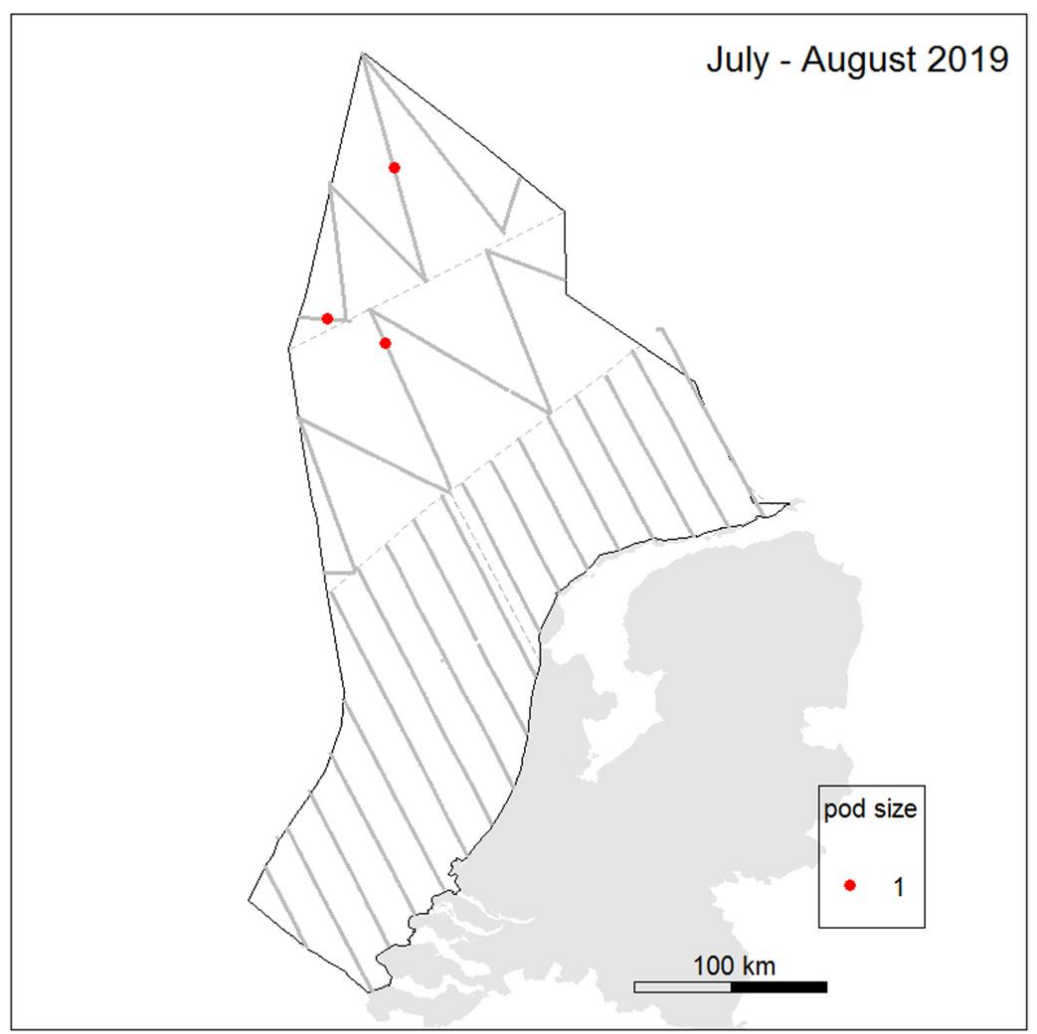

Figure 5. Minke whale sightings during the DCS survey in July-August 2019. 


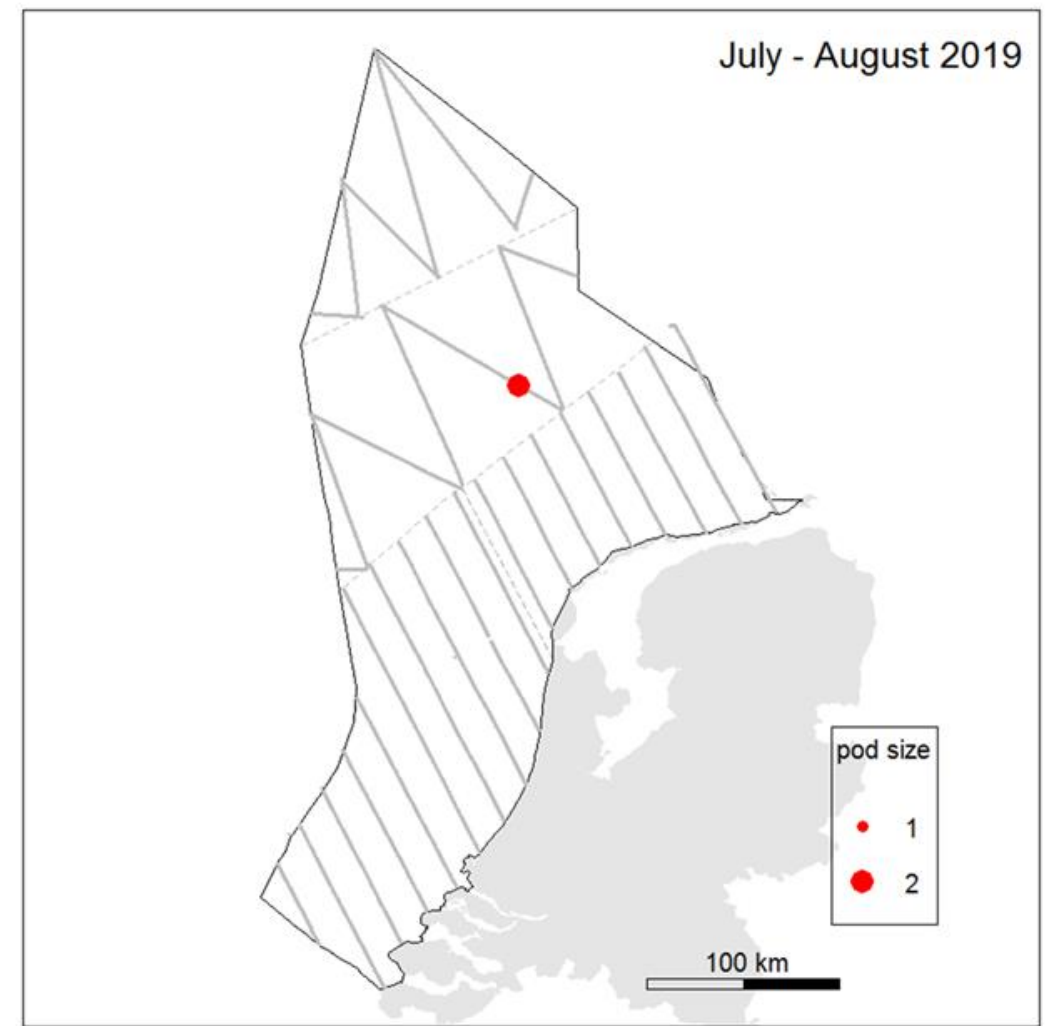

Figure 6. White-beaked Dolphin sightings during the DCS survey in July-August 2019.

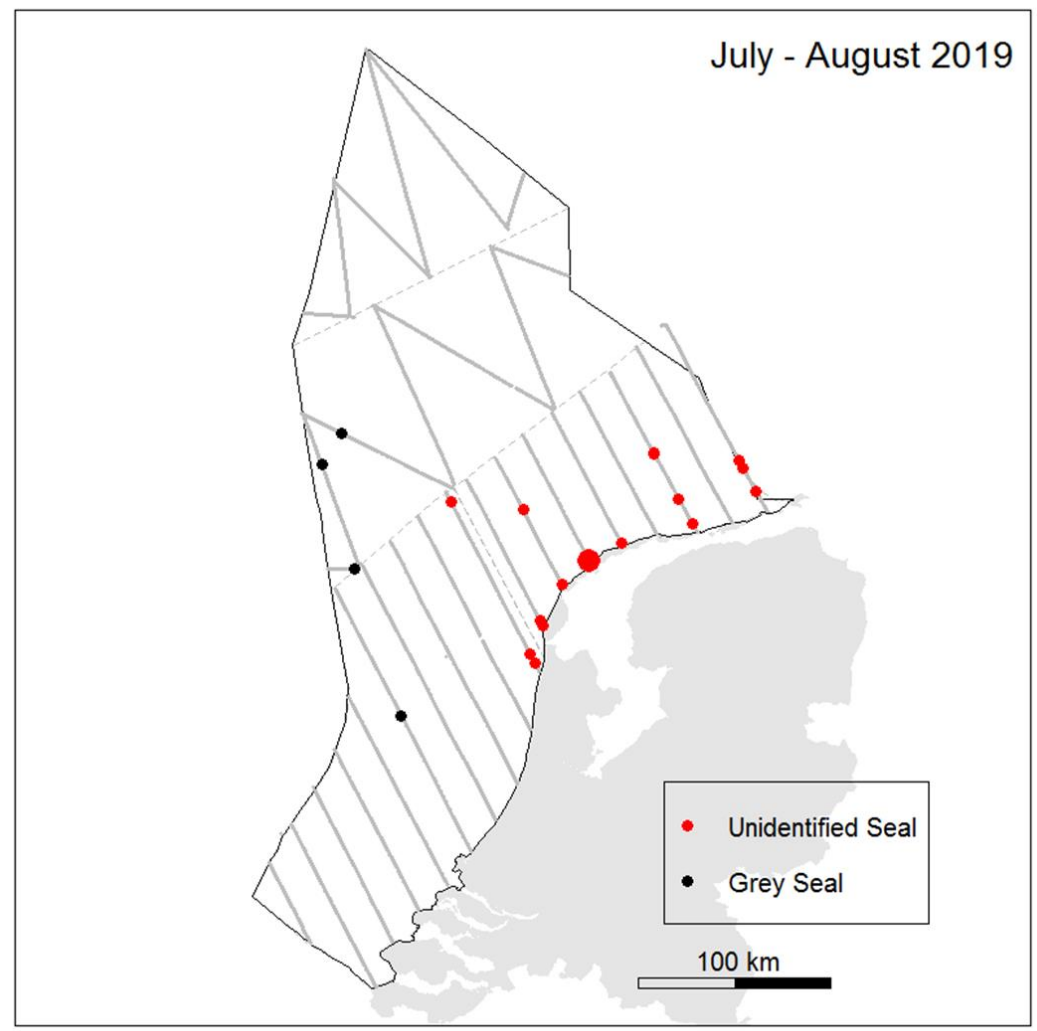

Figure 7. Seal sightings during the DCS survey in July-August 2019. 


\section{Discussion}

Wageningen Marine Research and its predecessor IMARES have been conducting aerial surveys in Dutch North Sea waters since May 2008. Five DCS wide surveys have been conducted previously in the month of July, in 2010, 2014, 2015, 2017 and 2018. Densities and abundance estimates of Harbour Porpoises are presented in Table 7 and the appendix, showing that summer densities vary between 0.14 and 3.08 animals $/ \mathrm{km}^{2}$ in the different years, highlighting that the density between the sub-areas is highly variable.

The abundance estimate for the DCS in 2019 of 38,911 individuals (CI = 20,791-76,822) lies between the minimum estimate in $2010(n=25,998 ; C I=13,988-53,623)$ and the maximum estimate in 2014 ( $n=76,773 ; C I=43,414-154,265$ ). Neither the DCS abundance estimate, nor the abundance estimates per sub-area show a trend. The confidence intervals of the abundance estimates overlap, indicating no statistically significant differences between the years. The time series, however, is relatively short to measure trends.

Table 7. Density and abundance estimates of Harbour Porpoises obtained in July 2010-2019 (Geelhoed et al. 2011, 2013a, 2014b. 2018, 2019, Geelhoed \& Scheidat 2018).

\begin{tabular}{lccccc}
\hline & $\begin{array}{c}\text { Density } \\
\left(\text { animals } / \mathbf{k m}^{2}\right)\end{array}$ & $\mathbf{C 9 5 \%} \mathbf{C I}$ & $\begin{array}{c}\text { Abundance } \\
\text { (n animals) }\end{array}$ & $\mathbf{9 5 \%} \mathbf{C I}$ & $\mathbf{C V}$ \\
\hline 2010 & 0.44 & $0.24-0.90$ & 25,998 & $13,988-53,623$ & 0.34 \\
\hline 2014 & 1.29 & $0.73-2.60$ & 76,773 & $43,414-154,265$ & 0.34 \\
\hline 2015 & 0.70 & $0.36-1.34$ & 41,299 & $21,194-79,256$ & 0.33 \\
\hline 2017 & 0.79 & $0.41-1.86$ & 46,902 & $24,389-93,532$ & 0.35 \\
\hline 2018 & 1.07 & $0.58-2.02$ & 63,514 & $34,276-119,734$ & 0.32 \\
\hline 2019 & 0.66 & $0.35-1.39$ & 38,911 & $20,791-76,822$ & 0.35 \\
\hline
\end{tabular}

The Harbour Porpoises in Dutch waters belong to the population that uses the wider North Sea (Evans et al., 2009). This whole area was surveyed during the summers of 2005 and 2016 (SCANS-II and SCANS-III), resulting in an abundance estimate of 355.000 and 345.000 individuals respectively (Hammond et al., 2013, 2017). Using a model-based approach, with the SCANS data and national surveys, Gilles et al. (2016) estimated the population size to number 361,000 individuals in 2005-2013. The results from the DCS surveys indicate that up to a fifth of the North Sea population has been present on the Dutch Continental Shelf in summer 2010-2019. 


\section{Conclusions}

The dedicated aerial survey of the Dutch Continental Shelf in summer 2019 resulted in an abundance estimate of 38,911 individuals ( $C I=20,791-76,822)$. This estimate falls within the range of abundance estimates since 2010 , with a minimum of 25,998 ( $C I=13,988-53,623$ in 2010) and a maximum of 76,773 (CI $=43,414-154,265$ in 2014) individuals. The confidence intervals of the abundance estimates overlap, indicating no statistically significant differences between the years. The time series, however, is relatively short to measure trends.

These abundance estimates show that up to a fifth of the North Sea population, estimated at 345,000361,000 individuals, has been present on the Dutch Continental Shelf during the summer surveys in 2010-2019.

The results of these aerial surveys will feed into the OSPAR MSFD indicator on abundance and distribution of marine mammals.

The Dutch aerial survey results has been used to assess the impact of anthropogenic activities in Dutch waters, as well as on an international scale. One impact is the bycatch of harbour porpoise in Dutch gillnet fisheries. Using the estimated bycatch rates in combination with the abundance estimates allowed an assessment of the scale of the impact on the (national) population (Scheidat et al., 2018). The Dutch aerial survey data has also been fed into an international database of all North Sea range states that apply the same 'SCANS-like' methodology. This includes survey efforts in Denmark, Germany, the UK and Belgium as well as the actual SCANS surveys. This database provided the data needed to model the impact of anthropogenic noise, such as produced through piling of wind mills, in the North Sea. It has also been used in other assessment schemes, such as presented by Merchant et al. (2018). The need for long-term comparable and high quality datasets remains high in the future as large-scale changes in the North Sea ecosystem are predicted. The highly mobile harbour porpoise reacts quickly to changes in the food availability, and as such is an indicator in the ecosystem. It is also a species considered especially vulnerable to a number of human activities and as such is a good indicator species for the impacts these can have on its population as well as the system. 


\section{Quality Assurance}

Wageningen Marine Research utilises an ISO 9001:2015 certified quality management system. This certificate is valid until 15 December 2021. The organisation has been certified since 27 February 2001. The certification was issued by DNV GL. 


\section{References}

Buckland ST, Anderson DR, Burnham KP, Laake JL, Borchers DL \& Thomas L, 2001. Introduction to Distance Sampling, Vol. Oxford University Press, Oxford.

Buckland ST, Anderson DR, Burnham KP, Laake JL, Borchers DL \& Thomas L, 2004. Advanced distance sampling. Oxford University press, New York, USA.

Camphuysen CJ \& Siemensma ML, 2011. Conservation plan for the Harbour Porpoise Phocoena phocoena in The Netherlands: towards a favourable conservation status. NIOZ Report 2011-07, Royal Netherlands Institute for Sea Research, Texel.

Evans P, Andersen LW, Bjørge A, Fontaine M, Galatius A, Kinze CC, Lockyer C, De Luna C, Pierce GJ, Sveegaard S, Teilmann J, Tiedemann R \& Walton M, 2009. Harbour porpoise Phocoena phocoena. Report of ASCOBANS/HELCOM small cetacean population structure workshop, 8-10 October 2007. UN Campus, Bonn, Germany.

Geelhoed S, Scheidat M, Aarts G, van Bemmelen R, Janinhoff N, Verdaat H \& Witte R, 2011. Shortlist Masterplan Wind - Aerial surveys of harbour porpoises on the Dutch Continental Shelf. Research Report IMARES Wageningen UR - Institute for Marine Resources \& Ecosystem Studies, Report No. C103/11.

Geelhoed SCV, Scheidat M, van Bemmelen RSA \& Aarts G, 2013a. Abundance of harbour porpoises (Phocoena phocoena) on the Dutch Continental Shelf, aerial surveys in July 2010-March 2011. Lutra 56(1): 45-57.

Geelhoed SCV, Scheidat M, \& van Bemmelen R, 2013b. Marine mammal surveys in Dutch waters in 2012. Research Report IMARES Wageningen UR - Institute for Marine Resources \& Ecosystem Studies, Report No. C038/13.

Geelhoed SCV, Scheidat M, \& van Bemmelen RSA, 2014a. Marine mammal surveys in Dutch waters in 2013. Research Report IMARES Wageningen UR - Institute for Marine Resources \& Ecosystem Studies, Report No. C027/14.

Geelhoed SCV, Lagerveld S, Verdaat JP \& Scheidat M, 2014b. Marine mammal surveys in Dutch waters in 2014. Research Report IMARES Wageningen UR - Institute for Marine Resources \& Ecosystem Studies, Report No. C180/14.

Geelhoed SCV, Lagerveld S \& Verdaat JP, 2015. Marine mammal surveys in Dutch North Sea waters in 2015. Research Report IMARES Wageningen UR - Institute for Marine Resources \& Ecosystem Studies, Report No. C189/15.

Geelhoed SCV, Janinhoff N, Lagerveld S, Lehnert LS \& Verdaat JP, 2018. Marine mammal surveys in Dutch North Sea waters in 2017. Wageningen Marine Research (University \& Research centre), Wageningen Marine Research report C030/18.

Geelhoed SCV \& Scheidat M, 2018. Abundance of harbour porpoises (Phocoena phocoena) on the Dutch Continental Shelf, aerial surveys 2012-2017. Lutra 61(1): 127-136.

Geelhoed SCV, Janinhoff N, Lagerveld S \& Verdaat JP, 2018. Marine mammal surveys in Dutch North Sea waters in 2019. Wageningen Marine Research (University \& Research centre), Wageningen Marine Research report C030/18

Gilles A, Scheidat M \& Siebert U, 2009. Seasonal distribution of harbour porpoises and possible interference of offshore wind farms in the German North Sea. Marine Ecology-Progress Series 383: 295-307.

Gilles A, Viquerat S, Becker EA, Forney KA, Geelhoed SCV, Haelters J, Nabe-Nielsen J, Scheidat M, Siebert U, Sveegaard S, van Beest FM, van Bemmelen R \& Aarts G, 2016. Seasonal habitatbased density models for a marine top predator, the harbor porpoise, in a dynamic environment. Ecosphere7 (6):e01367. 10.1002/ecs2.1367

Hammond PS, Macleod K, Berggren P, Borchers DL, Burt ML, Cañadas A, Desportes G, Donovan GP, Gilles A, Gillespie D, Gordon J, Hedley S, Hiby L, Kuklik I, Leaper R, Lehnert K, Leopold M, Lovell $P$, Øien N, Paxton C, Ridoux V, Rogan E, Samarra F, Scheidat M, Sequeira M, Siebert U, Skov H, Swift R, Tasker ML, Teilmann J, Van Canneyt O \& Vázquez JA, 2013. Cetacean abundance and distribution in European Atlantic shelf waters to inform conservation and management. Biological Conservation, 164: 107-122. 
Hammond PS, Lacey C, Gilles A, Viquerat S, Börjesson P, Herr H, Macleod K, Ridoux V, Santos MB, Scheidat M, Teilmann J, Vingada J \& Øien N, 2017. Estimates of cetacean abundance in European Atlantic waters in summer 2016 from the SCANS-III aerial and shipboard surveys.

Merchant ND, Faulkner RD \& Martinez R, 2018. Marine Noise Budgets in Practice. Conservation Letters 11(3): 1-8.

SCANS, 2008. Small Cetaceans in the European Atlantic and North Sea. Final report to the European Commission under project LIFE04NAT/GB/000245. Available from SMRU, Gatty Marine Laboratory, University of St. Andrews, St. Andrews, Fife, UK.

Scheidat M, Gilles A, Kock K \& Siebert U, 2008. Harbour porpoise Phocoena phocoena abundance in the south-western Baltic Sea. Endangered Species Research 5: 215-223.

Scheidat M, Verdaat H \& Aarts G, 2012. Using aerial surveys to estimate density and distribution of harbour porpoises in Dutch waters. Journal of Sea Research 69: 1-7.

Scheidat M, Couperus B, Siemensma M, 2018. Electronic monitoring of incidental bycatch of harbour porpoise (Phocoena phocoena) in the Dutch bottom set gillnet fishery (September 2013 to March 2017). Wageningen Marine Research (University \& Research centre), Wageningen University \& Research report C102/18. 


\section{Appendix: abundance estimates and densities, 2010-2019}

\begin{tabular}{|c|c|c|c|c|c|}
\hline 2019 & $\begin{array}{c}\text { Density } \\
\left(\text { animals } / \mathbf{k m}^{2}\right)\end{array}$ & C95\% CI & $\begin{array}{l}\text { Abundance } \\
\text { (n animals) }\end{array}$ & $95 \% \mathrm{CI}$ & CV \\
\hline Area A - Dogger Bank & 0.46 & $0.11-1.05$ & 4380 & $1017-10,056$ & 0.51 \\
\hline Area B - Offshore & 0.68 & $0.29-1.39$ & 11,557 & $4825-23,437$ & 0.38 \\
\hline Area C - Frisian Front & 0.69 & $0.40-1.34$ & 8262 & $4780-16,093$ & 0.32 \\
\hline Area D - Delta & 0.71 & $0.24-1.64$ & 14,713 & $4987-34,130$ & 0.48 \\
\hline Total DCS & 0.66 & $0.35-1.39$ & 38,911 & $20,791-76,822$ & 0.35 \\
\hline 2018 & $\begin{array}{c}\text { Density } \\
\left(\text { animals } / \mathbf{k m}^{2}\right)\end{array}$ & C95\% CI & $\begin{array}{l}\text { Abundance } \\
\text { (n animals) }\end{array}$ & $95 \%$ CI & CV \\
\hline Area A - Dogger Bank & 0.63 & $0.30-1.43$ & 6020 & $2859-13,704$ & 0.41 \\
\hline Area B - Offshore & 1.76 & $0.87-3.44$ & 29,722 & $14,663-58,170$ & 0.36 \\
\hline Area C - Frisian Front & 1.38 & $0.63-2.84$ & 16,595 & $7618-34,120$ & 0.37 \\
\hline Area D - Delta & 0.54 & $0.26-1.06$ & 11,176 & $5400-22,078$ & 0.35 \\
\hline Total DCS & 1.07 & $0.58-2.02$ & 63,514 & $34,276-119,734$ & 0.32 \\
\hline \multicolumn{6}{|l|}{2017} \\
\hline Area A - Dogger Bank & 0.14 & $0.01-0.29$ & 1325 & $167-2833$ & 0.46 \\
\hline Area B - Offshore & 1.28 & $0.55-2.92$ & 21,584 & $9229-49,331$ & 0.44 \\
\hline Area C - Frisian Front & 0.53 & $0.08-1.53$ & 6360 & $991-18,402$ & 0.64 \\
\hline Area D - Delta & 0.85 & $0.41-1.66$ & 17,631 & $8595-34,552$ & 0.37 \\
\hline Total DCS & 0.79 & $0.41-1.86$ & 46,902 & $24,389-93,532$ & 0.35 \\
\hline \multicolumn{6}{|l|}{2015} \\
\hline Area A - Dogger Bank & 1.12 & $0.43-2.25$ & 10,748 & $4113-21,676$ & 0.39 \\
\hline Area B - Offshore & 0.80 & $0.17-1.20$ & 13,573 & $7002-26,606$ & 0.35 \\
\hline Area C - Frisian Front & 0.44 & $0.20-0.98$ & 5304 & $2354-11,798$ & 0.43 \\
\hline Area D - Delta & 0.56 & $0.41-1.58$ & 11,674 & $3542-24,958$ & 0.45 \\
\hline Total DCS & 0.70 & $0.36-1.34$ & 41,299 & $21,194-79,256$ & 0.33 \\
\hline \multicolumn{6}{|l|}{2014} \\
\hline Area A - Dogger Bank & 3.08 & $1.50-6.45$ & 29,689 & $14,375-61,995$ & 0.37 \\
\hline Area B - Offshore & 0.37 & $0-1.21$ & 6297 & $0-20,509$ & 0.96 \\
\hline Area C - Frisian Front & 1.83 & $0.97-4.11$ & 22,010 & $11,623-49,439$ & 0.39 \\
\hline Area D - Delta & 0.90 & $9.46-1.84$ & 18,778 & $9548-38,167$ & 0.36 \\
\hline Total DCS & 1.29 & $0.73-2.60$ & 76,773 & $43,414-154,265$ & 0.34 \\
\hline \multicolumn{6}{|l|}{2010} \\
\hline Area A - Dogger Bank & 0.40 & $0.18-0.85$ & 3806 & $1738-8165$ & 0.40 \\
\hline Area B - Offshore & 0.48 & $0.21-1.06$ & 8055 & $3589-17,872$ & 0.42 \\
\hline Area C - Frisian Front & 0.34 & $0.05-0.89$ & 4039 & $553-10,701$ & 0.62 \\
\hline Area D - Delta & 0.48 & $0.21-1.06$ & 10,098 & $4341-22,024$ & 0.40 \\
\hline Total DCS & 0.44 & $0.24-0.90$ & 25,998 & $13,988-53,623$ & 0.34 \\
\hline
\end{tabular}




\section{Justification}

Report C016/20

Project Number: 4312100087

The scientific quality of this report has been peer reviewed by a colleague scientist and a member of the Management Team of Wageningen Marine Research

Approved: $\quad$ Meike Scheidat

Senior researcher

Wageningen Marine Research

Signature:

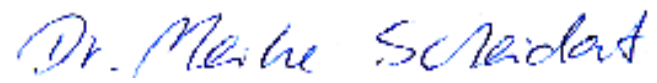

Date: 24 February 2020

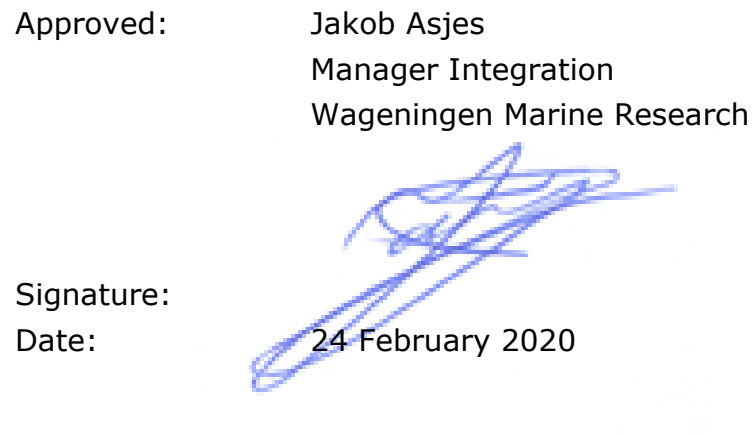


Wageningen Marine Research

$\mathrm{T}+31(0) 317480900$

E: marine-research@wur.nl

www.wur.eu/marine-research

Visitors' address

- Ankerpark 271781 AG Den Helder

- Korringaweg 7, 4401 NT Yerseke

- Haringkade 1, 1976 CP IJmuiden
With knowledge, independent scientific research and advice, Wageningen Marine Research substantially contributes to more sustainable and more careful management, use and protection of natural riches in marine, coastal and freshwater areas

Wageningen Marine Research is part of Wageningen University \& Research. Wageningen University \& Research is the collaboration between Wageningen University and the Wageningen Research Foundation and its mission is: 'To explore the potential for improving the quality of life' 